\title{
Influence of Cortisone on Ascorbic-acid Requirements of Guinea- pigs: an Assessment by the Tooth-structure Method
}

\author{
By L. J. HARRIS, B. J. CONSTABLE, R. E. HUGHES AND G. LOEWI \\ Dunn Nutritional Laboratory, University of Cambridge and \\ Medical Research Council
}

(Received 12 March 1955)

The apparent connexion between vitamin $\mathrm{C}$ and the adrenal gland has been the subject of much speculation and experimentation. That high concentrations of ascorbic acid are found in the adrenals, in both the cortex (Szent-Györgyi, 1928; Harris, Mills \& Innes, I932; Harris \& Ray, 1932, 1933 $a$ ) and the medulla (Harris \& Ray, I933 $b$ ), draws attention to a possible relationship. Again, it may be significant that a wellknown effect of ACTH is to cause a transient fall in the concentration of vitamin C in the adrenal glands (Sayers, Sayers, Lewis \& Long, 1944). Some workers have claimed that cortisone or ACTH can postpone scurvy or otherwise influence the vitamin $\mathrm{C}$ requirements of an animal (e.g. Hyman, Ragan \& Turner, 1950; Eisenstein \& Shank, I95I): others, on the contrary, have been unable to demonstrate any connexion (e.g. Clayton \& Prunty, 195I). In our own preliminary endeavours to explore the question quantitatively we tested the effect of these two hormones either on the growth or on the survival periods of animals receiving various graded intakes of the vitamin. Although our results were substantially negative we thought that their interpretation might possibly be ambiguous. The two methods of assay are those that have been used by previous workers on this problem, but are not sufficiently specific to give a completely unequivocal answer. Large doses of the hormones, no less than of the vitamin, can have an independent influence on food intakes, on weight curves, and on survival periods: hence any attempt to show a correlation by such means is open to question. We therefore concluded that to test the supposed relationship it would be necessary to use a specific criterion, namely the effect of vitamin $\mathrm{C}$ deficiency on tooth structure. So far as is known, no other factor has the highly characteristic effect of vitamin $\mathrm{C}$ deficiency in causing remarkable and distinctive changes in the odontoblasts and other dental structures (Höjer \& Westin, I925; Fish \& Harris, 1934). It would therefore seem that this procedure is the only one able to give an unmistakable answer to the question posed. As will appear below, our results indicate that, under the conditions of our tests, cortisone is without demonstrable effect on the overall vitamin $\mathrm{C}$ requirements. This finding is in line with our earlier conclusions that neither ACTH nor cortisone substantially influenced ascorbic-acid economy as a whole (Hughes, Harris, Constable \& Bland, 1952; Bland, Constable, Harris \& Hughes, I952 $a, b$; Harris, Bland, Hughes \& Constable, I953). 


\section{EXPERIMENTAL}

For determining the degree of protection against scorbutic changes afforded by various graded doses of ascorbic acid, either with or without the concurrent daily administration of cortisone, the assay procedure described by Harris \& Olliver (1942), based on the method of Key \& Elphick (193I), was rigidly followed.

Preliminary period. Male guinea-pigs weighing approximately $280 \mathrm{~g}$ were placed on the following diet: Sussex-ground oats $57 \cdot 5$, bran $13 \cdot 0$, white fish meal $21 \cdot 5$, dried yeast $8 \cdot 0$, salt mixture $2 \cdot 0$, parts by weight. Supplements added were: cabbage I $5 \mathrm{~g} /$ day, halibut-liver oil I drop/week, vitamin $\mathrm{K}$ (2-methyl-I:4-naphthoquinone, $5 \%(\mathrm{w} / \mathrm{w})$ in arachis oil) I drop/week and vitamin $\mathrm{E}(\alpha$-tocopheryl acetate, $5 \%(\mathrm{w} / \mathrm{w})$ in arachis oil) I drop/week.

Test period. On the day that each animal reached a weight of $300 \mathrm{~g}$, the allowance of cabbage was discontinued. These animals were then distributed evenly over five experimental groups, whose vitamin $C$ allowances were as follows: $0,0.5, I \cdot 0,2 \cdot 0$ and $4^{\circ} \circ \mathrm{mg}$ ascorbic acid daily (per os in a solution of $\mathrm{I} \%(\mathrm{w} / \mathrm{v})$ citric acid). A sixth, control, group received $\mathbf{I} 5 \mathrm{~g}$ cabbage daily. There were twelve animals in each group, six of which were given $7.5 \mathrm{mg}$ cortisone daily (in three doses of $2.5 \mathrm{mg}$ cortisone acetate, Roussel Laboratories, 847 Harrow Road, London, N.W. 10), injected intramuscularly (alternately into each hind-leg); and the other six were given a dummy injection of isotonic saline.

Histological preparation. After precisely I 4 days on the test period each animal was killed by coal gas, the lower incisor teeth were removed (with a portion of the mandible), fixed in $4 \%(\mathrm{w} / \mathrm{v})$ formaldehyde plus $2 \%(\mathrm{v} / \mathrm{v})$ acetic acid for at least 3 days, decalcified in $10 \%(\mathrm{v} / \mathrm{v})$ nitric acid with daily changes, dehydrated rapidly in absolute alcohol, and treated with chloroform for $12 \mathrm{~h}$ to remove the alcohol. The teeth were then embedded in paraffin and sectioned at $7 \mu$. The sections were stained with Ehrlich's acid haematoxylin and eosin in the usual way.

Assessment of 'degree of protection'. To minimize as far as possible the subjective errors in any method of assay based on visual comparisons, the following procedure was adopted. (I) Photomicrographs of the sections were prepared and were compared, as were also the sections themselves. (2) Scores were separately assessed by each of four individual assessors, working independently, and the average of their findings was used.

Criteria. Each section was awarded a score of from o to 4 points, the criteria being essentially the same as those previously accepted by Key \& Elphick (I93I) and by Harris \& Olliver (1942). The assessors were asked to pay special attention to three factors, namely (I) the degree of degeneration of the odontoblasts, (2) the length of the odontoblasts and (3) the width of the layer of inner dentine. (In severe deficiency the odontoblasts are short and highly disorganized, and there is a wide layer of calcified inner dentine; in the protected animal the odontoblasts are long, regular in formation and parallel, and there is no calcified inner dentine. With intermediate degrees of deficiency the picture is intermediate.) In assessing the score, reference was made to the photographic standards set up by Key \& Elphick (I93I), as well as to a corresponding set of standard sections used for many years in this laboratory. 
Parallel determinations on adrenal ascorbic acid. As we have found (Constable, Harris \& Hughes, r955) that, in certain circumstances, the depletion of vitamin C from the adrenal can afford an indication of cortisone action, e.g. when administered continuously over long periods to guinea-pigs on low vitamin intakes, comparable determinations were made in all instances of adrenal ascorbic-acid concentrations, the test method being titration against 2:6-dichlorophenolindophenol with the use of a photoelectric colorimeter (employed essentially in the way described by Mindlin \& Butler, 1937).

As a further check, the criterion of increase in liver weight (Harris et al. 1953) was also used to prove the potency of the cortisone used.

\section{RESULTS}

\section{Dental changes}

The averages of the scores awarded by the referees, and the individual ratings, are given in Table 1 . The dose-response curves are shown in Fig. 1 , and the corresponding calculations of the relative activity of the ascorbic acid alone or with concurrent administration of cortisone are given below.

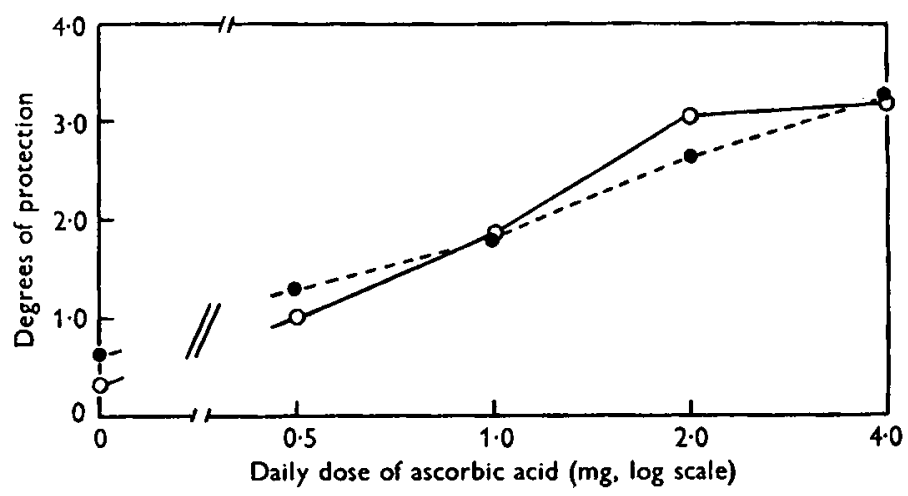

Fig. I. Dose-response curve for degrees of protection (see p. 3 I I) by ascorbic acid, with and without concurrent administration of cortisone. $0-0$, cortisone treated guinea-pigs; $\bullet---\bullet$, controls.

The dose-response curve shows that cortisone had no demonstrable effect in protecting against the deficiency. Statistical treatment, for which we are indebted to Dr J. O. Irwin, confirms that there is no significant difference, either in the position or in the slope of the two curves.

Statistical comparison. Dr Irwin's report is as follows:

A comparison has been made of the curves relating degree of protection to dose of ascorbic acid in the control and cortisone-treated animals (Table $\mathrm{r}$ ). For the present purpose it is clearly adequate to assume a linear relation between degree of protection $(y)$ and $\log$ dose $(x)$.

Taking $y=$ degree of protection, $x=\log \left(\right.$ dose in $\mathrm{mg}$ ) $-\frac{1}{2} \log 2$ (which is equivalent 
Table I. Effect of cortisone upon the dental changes and adrenal ascorbic acid in guinea-pigs kept on low intakes of ascorbic acid

\begin{tabular}{|c|c|c|c|c|c|c|c|c|}
\hline \multirow[b]{3}{*}{$\begin{array}{l}\text { Ascorbic- } \\
\text { acid intake } \\
\text { (mg/day) }\end{array}$} & \multirow[b]{3}{*}{$\underset{\text { no. }}{\text { Animal }}$} & \multicolumn{3}{|c|}{ Control animals } & \multicolumn{4}{|c|}{ Cortisone-treated animals } \\
\hline & & \multicolumn{2}{|c|}{ Degree of protection } & \multirow{2}{*}{$\begin{array}{c}\text { Adrenal } \\
\text { ascorbic acid } \\
(\mathrm{mg} / \mathrm{I} 00 \mathrm{~g})\end{array}$} & \multirow[b]{2}{*}{$\begin{array}{c}\text { Animal } \\
\text { no. }\end{array}$} & \multicolumn{2}{|c|}{ Degree of protection } & \multirow{2}{*}{$\begin{array}{c}\text { Adrenal } \\
\text { ascorbic acid } \\
(\mathrm{mg} / \mathrm{I} \text { oo } \mathrm{g})\end{array}$} \\
\hline & & $\begin{array}{l}\text { Individual } \\
\text { ratings }\end{array}$ & Mean & & & $\begin{array}{l}\text { Individual } \\
\text { ratings }\end{array}$ & Mean & \\
\hline \multirow[t]{6}{*}{0} & $\mathbf{I}$ & $0,0,1 \cdot 0,0$ & 0.25 & I6.6 & 28 & $0 \cdot 5,0,1 \cdot 0,0$ & 0.38 & $7 \cdot 4$ \\
\hline & 2 & $0,0,0.5,0$ & 0.13 & 13.4 & 29 & $0.75,0.5,1 \cdot 0,1$ & 0.81 & $6 \cdot 6$ \\
\hline & 3 & $I \cdot 0,0 \cdot 5, I \cdot 0,2$ & I'1 3 & $15 \cdot 2$ & 30 & $0.5,0,1 \cdot 0,0$ & 0.38 & $6 \cdot 2$ \\
\hline & 4 & $I \cdot 25,0 \cdot 75,2 \cdot 0, I$ & $I \cdot 25$ & $8 \cdot 6$ & 31 & $0,0,0,0$ & 0 & $1 \cdot 5$ \\
\hline & 5 & $0.25,0,1 \cdot 0,0$ & 0.32 & $7 \cdot 4$ & 32 & $0,0,0,0$ & $\circ$ & $2 \cdot 0$ \\
\hline & Mean & & 0.62 & $12 \cdot 2$ & Mean & & 0.31 & $4 \cdot 7$ \\
\hline \multirow[t]{6}{*}{0.5} & 6 & $0.5,0.5,0.5, \mathrm{I}$ & 0.63 & $18 \cdot 4$ & 33 & $1 \cdot 5,1 \cdot 0,2 \cdot 5,1$ & $x \cdot 50$ & $16 \cdot 6$ \\
\hline & 7 & $0.75,1 \cdot 0,3 \cdot 0, I$ & $I \cdot 44$ & $18 \cdot 5$ & 34 & $I \cdot 0, I \cdot 5, I \cdot 5,2$ & $1 \cdot 50$ & I $3 \cdot 7$ \\
\hline & 8 & $0.5,0,1 \cdot 5,0$ & 0.50 & $23 \cdot 2$ & 35 & $1 \cdot 0,0,3 \cdot 0,0$ & $I \cdot 00$ & $I I \cdot 2$ \\
\hline & 9 & $1 \cdot 5,1 \cdot 0,2 \cdot 5,4$ & $2 \cdot 25$ & $16 \cdot 5$ & 36 & $0.5,0,0.5,1$ & 0.50 & 17.4 \\
\hline & IO & $2 \cdot 0, x \cdot 0,2 \cdot 5,1$ & $I \cdot 63$ & $16 \cdot 0$ & 37 & $0 \cdot 5,0, x \cdot 5,0$ & 0.50 & I $3 \cdot 2$ \\
\hline & Mean & & $I \cdot 29$ & $18 \cdot 5$ & Mean & & $I \cdot 00$ & $14 \cdot 4$ \\
\hline \multirow[t]{6}{*}{$1 \cdot 0$} & II & $2 \cdot 0,2 \cdot 0,4 \cdot 0,2$ & $2 \cdot 50$ & $30 \cdot 5$ & $3^{8}$ & $I \cdot 0, x \cdot 5, I \cdot 0, I$ & $I \cdot 13$ & I $8 \cdot 8$ \\
\hline & I 2 & $I \cdot 5,2 \cdot 5,3^{\cdot} \mathrm{O}, \mathrm{I}$ & $2 \cdot 00$ & $28 \cdot 2$ & 39 & $2 \cdot 5,2 \cdot 0,3 \cdot 5,4$ & 3.00 & $17 \cdot 4$ \\
\hline & I3 & $1 \cdot 0,0.75,1 \cdot 0, I$ & 0.94 & $18 \cdot 3$ & 40 & $1 \cdot 0, x \cdot 5,1 \cdot 5,2$ & $1 \cdot 50$ & $18 \cdot 4$ \\
\hline & 14 & $I \cdot 0,2 \cdot 0,2 \cdot 5, I$ & $I \cdot 63$ & $26 \cdot 0$ & $4 x$ & $I \cdot 5, I \cdot 0,2 \cdot 5,2$ & $I \cdot 75$ & $I 7 \cdot I$ \\
\hline & $\begin{array}{l}\text { I5 } \\
\text { I6 }\end{array}$ & $\begin{array}{l}2 \cdot 5, \mathbf{I} \cdot 0,3 \cdot 0, \mathbf{I} \\
1 \cdot 0, \mathbf{I} \cdot 75,2 \cdot 5,2\end{array}$ & $\begin{array}{l}I \cdot 88 \\
I \cdot 8 I\end{array}$ & $\begin{array}{l}23 \cdot 5 \\
21 \cdot 6\end{array}$ & & & & \\
\hline & Mean & & $I \cdot 79$ & $24: 7$ & Mean & & $r \cdot 85$ & I7・9 \\
\hline \multirow[t]{7}{*}{$2 \cdot 0$} & 17 & $2 \cdot 0,2 \cdot 0,4$ & $2 \cdot 67$ & $37 \cdot 0$ & 42 & $3 \cdot 0,3 \cdot 0,3 \cdot 5,4$ & $3 \cdot 38$ & $28-8$ \\
\hline & 18 & $2 \cdot 0,2 \cdot 5,2 \cdot 5,2$ & $2 \cdot 25$ & $27 \cdot 7$ & 43 & $3 \cdot 0,2 \cdot 0,3 \cdot 5,2$ & $2 \cdot 63$ & $3^{8 \cdot I}$ \\
\hline & 19 & $2 \cdot 5,1 \cdot 75,3 \cdot 0,2$ & $2 \cdot 31$ & $4 I \cdot I$ & 44 & $3 \cdot 5,3 \cdot 0,2 \cdot 5,4$ & $3 \cdot 25$ & $39 \cdot 3$ \\
\hline & 20 & $3 \cdot 0,2 \cdot 0,3 \cdot 0,2$ & $2 \cdot 50$ & $39 . I$ & 45 & $3 \cdot 0,2 \cdot 5,3 \cdot 0,4$ & 3.13 & 28.7 \\
\hline & 21 & $3 \cdot 5,3 \cdot 0,4 \cdot 0,4$ & $3 \cdot 63$ & $41 \cdot 6$ & 46 & $3 \cdot 0,3 \cdot 0,3 \cdot 5,2$ & $2 \cdot 88$ & $4 I^{-4}$ \\
\hline & 22 & $2 \cdot 0,2 \cdot 0,2 \cdot 5,3$ & $2 \cdot 3^{8}$ & $20 \cdot 3$ & & & & \\
\hline & Mean & & $2 \cdot 62$ & $34 \cdot 5$ & Mean & & $3 \cdot 05$ & $35 \cdot 3$ \\
\hline \multirow[t]{7}{*}{$4 \cdot 0$} & 23 & $3.5,3 \cdot 0,3.5,4$ & $3 \cdot 50$ & $53 \cdot 8$ & 47 & $4^{\circ} \circ, 3^{\circ} \circ, 3^{\circ} \circ, 2$ & 3.00 & $31 \cdot 0$ \\
\hline & 24 & $3 \cdot 0,2 \cdot 5,3 \cdot 5,3$ & 3.00 & $31 \cdot 0$ & 48 & $3 \cdot 5,2 \cdot 5,4 \cdot 0,3$ & $3 \cdot 25$ & $48 \cdot 8$ \\
\hline & 25 & $3 \cdot 0,3 \cdot 0,3 \cdot 5,4$ & $3 \cdot 38$ & $42 \cdot 8$ & 49 & $2 \cdot 5,2 \cdot 5,3 \cdot 5,3$ & $2 \cdot 88$ & 33.5 \\
\hline & 26 & $3 \cdot 5,3 \cdot 0,4 \cdot 0,4$ & $3 \cdot 63$ & $33 \cdot 3$ & 50 & $3 \cdot 5,2 \cdot 5,3 \cdot 5,3$ & $3 \cdot 13$ & $36 \cdot 4$ \\
\hline & 27 & $3 \cdot 0,2 \cdot 5,2 \cdot 5,3$ & 275 & $41 \cdot 0$ & 51 & $3 \cdot 0,3^{\circ} 0,3 \cdot 5,3$ & $3 \cdot 13$ & $36 \cdot 8$ \\
\hline & & & & & 52 & $4 \cdot 0,3^{\circ} 0,3 \cdot 5,4$ & $3 \cdot 63$ & $47 \cdot I$ \\
\hline & Mean & & $3 \cdot 25$ & 40.4 & Mean & & $3 \cdot 17$ & $38 \cdot 9$ \\
\hline
\end{tabular}

The original number of animals in the five groups quoted in this table was sixty, but in a few instances satisfactory histological sections were not obtained.

to taking the origin at a point corresponding to $\sqrt{2}=1.414 \mathrm{mg}$ ), I find the following dose-response curves:

$$
\text { Controls } \quad \begin{aligned}
Y & =2 \cdot 23+\mathrm{I} \cdot 19 x, \\
\text { Treated } \quad Y & =2 \cdot 32+\mathrm{I} \cdot 4 \mathrm{I}(x-0 \cdot 06) \\
& =2 \cdot 24+\mathrm{I} \cdot 4 \mathrm{I} x .
\end{aligned}
$$

(The zero doses are, of course, not included.) 
314 L. J. Harris, B. J. Constable, R. E. Hughes and G. Loewi 1955

These two curves can be compared with regard to position $(\bar{y})$ and slope $b$.

$\begin{array}{lcccc} & \bar{y} & \text { S.E. } & b & \text { S.E. } \\ \text { Controls } & 2 \cdot 23\left(\mathrm{I} \cdot 93^{*}\right) & 0 \cdot 12 & \mathrm{I} \cdot 19 & 0 \cdot 19 \\ \text { Treated } & 2 \cdot 32\left(\mathrm{I} \cdot 92^{*}\right) & 0 \cdot \mathrm{II} & \mathrm{I} \cdot 4 \mathrm{I} & 0 \cdot 17\end{array}$

* Mean values including controls.

There are clearly no significant differences in position or slope.

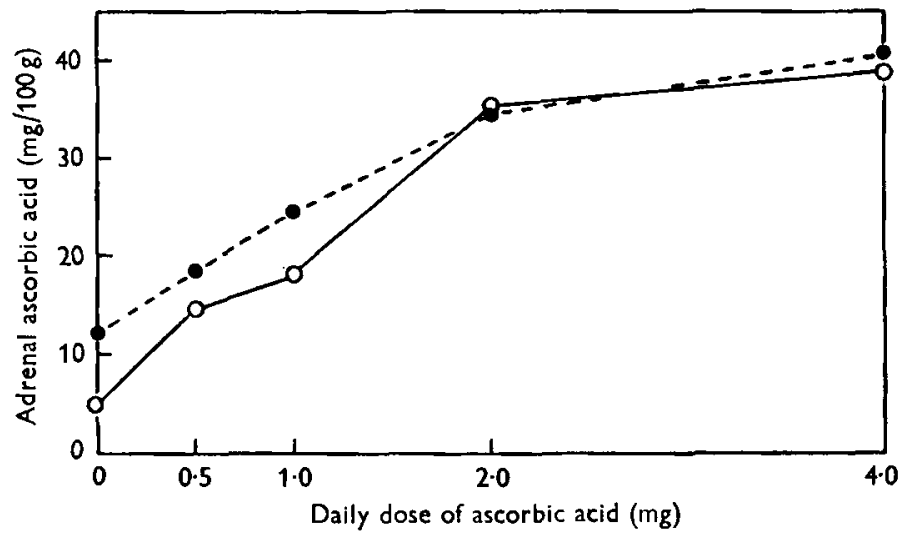

Fig. 2. Concentration of ascorbic acid in adrenals, at various levels of intake, as influenced by concurrent administration of cortisone. $0-0$, cortisone treated guinea-pigs; $\bullet---\bullet$, controls.

Table 2. Increase in liver weight in guinea-pigs receiving cortisone, with various intakes of ascorbic acid

Liver weight as percentage of body-weight

\begin{tabular}{|c|c|c|c|c|c|}
\hline \multirow{2}{*}{$\begin{array}{l}\text { Ascorbic- } \\
\text { acid intake } \\
(\mathrm{mg} / \text { day })\end{array}$} & \multirow{2}{*}{$\underbrace{\text { Control animals }}_{\text {Individual values }}$} & \multirow[b]{2}{*}{ Mean } & Cortisone-treated animals & & \multirow{2}{*}{$\begin{array}{c}\text { Increase } \\
(\%)\end{array}$} \\
\hline & & & Individual values & Mean & \\
\hline$\circ$ & $2 \cdot 95,3 \cdot 74,3 \cdot 5 \mathrm{I}, 3 \cdot 92,3 \cdot 10,3 \cdot 90$ & 3.52 & $5 \cdot 75,3 \cdot 92,6.90,3 \cdot 78,6.07,5 \cdot 10$ & $5 \cdot 25$ & 49 \\
\hline 0.5 & $3.47,3.63,4.04,3.28,3.39,3.45$ & 3.54 & $5 \cdot 44,5 \cdot 05,6 \cdot 70,4 \cdot 92,5 \cdot 62,4.47$ & $5 \cdot 37$ & 52 \\
\hline $1 \cdot 0$ & $3 \cdot 28,4.85,4.27,4 \cdot 53,4 \cdot 23,4.27$ & $4 \cdot 24$ & $6.03,5 \cdot 36,4 \cdot 19,6 \cdot 06,6 \cdot 91,3 \cdot 30$ & $5 \cdot 31$ & 25 \\
\hline $2 \cdot 0$ & $3.91,3.58,3.63,3 \cdot 24,3 \cdot 82,3.95$ & 3.69 & $6 \cdot 67,4 \cdot 32,5 \cdot 52,5 \cdot 69,5 \cdot 75,5 \cdot 34$ & 5.55 & 50 \\
\hline 4.0 & $3 \cdot 74,2 \cdot 98,3 \cdot 87,3 \cdot 30,3 \cdot 43,4 \cdot 21$ & 3.59 & $4.81,4^{\cdot 33}, 5^{.62}, 5^{\cdot 22}, 5^{\circ} 00,5^{.60}$ & $5 \cdot 10$ & 42 \\
\hline $\begin{array}{l}\text { From is } \mathrm{g} \\
\text { cabbage }\end{array}$ & $3 \cdot 52,4^{\cdot 22}, 4^{\cdot 27}, 4^{\cdot 10}, 4^{\cdot 13}$ & 4.05 & $7 \cdot 10,6 \cdot 32,4^{\cdot} \cdot 76,4 \cdot 90,4 \cdot 26$ & $5 \cdot 47$ & 35 \\
\hline
\end{tabular}

\section{Adrenal ascorbic acid}

Proof that the cortisone used was indeed active is afforded by the figures for ascorbic acid in the adrenals (Table $I$ and Fig. 2). The depletion is most readily apparent in the groups on the lower intakes of vitamin $\mathrm{C}$ and is not seen at all at the two top levels of intake ( 2 and $4 \mathrm{mg}$ ).

\section{Liver weights}

A further proof of the potency of the preparation of cortisone is seen in the figures for liver weights (Table 2 and Fig. 3). It will be noted that these were increased by the cortisone treatment, irrespective of the level of intake of vitamin C. 
DISCUSSION

Our results indicate that, although cortisone caused a loss of ascorbic acid from the adrenals in the deficient animals, it was without significant effect on the development of deficiency signs, as judged quantitatively. This must mean that the disappearance from the adrenal gland is in the nature only of a localized mobilization or turnover and does not indicate an appreciable loss of vitamin $\mathrm{C}$ from the body as a whole.

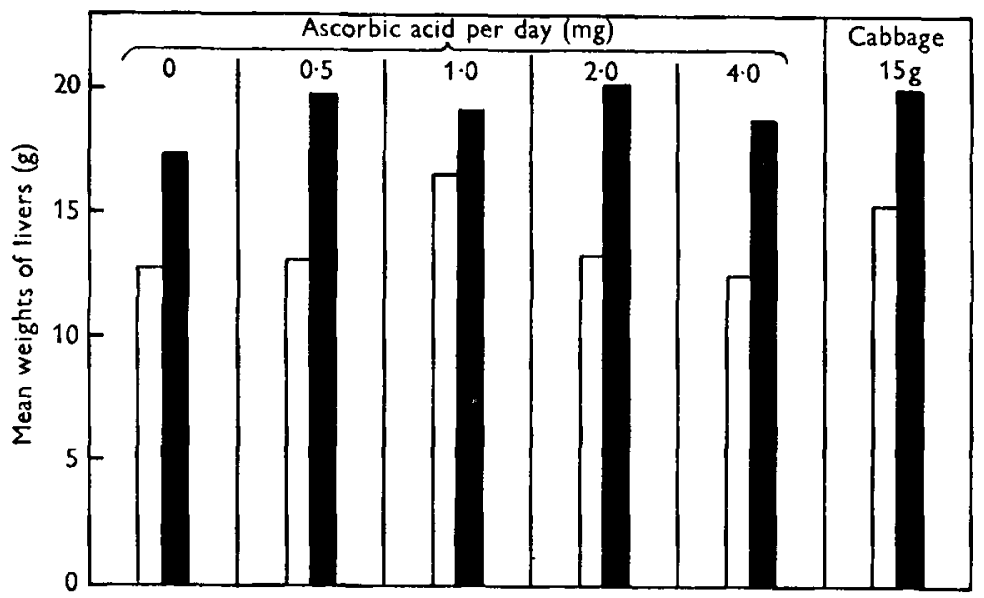

Fig. 3. Effect of cortisone on weight of liver at various levels of intake of ascorbic acid.

$\square$, cortisone-treated guinea-pigs; $\square$, controls.

\section{SUMMARY}

r. Groups of guinea-pigs were given graded doses of ascorbic acid; their degree of protection from deficiency was assessed by the dental-histology method; and the corresponding dose-response curve was constructed. A second set of guinea-pigs received identical treatments except that, in addition to the graded doses of vitamin C, daily injections of cortisone $(7.5 \mathrm{mg})$ were administered. Twelve animals were used at each such level of vitamin $\mathrm{C}$ intake, six receiving the cortisone and six having dummy injections.

2. No appreciable difference was found in the resulting dose-response curves, as between the animals receiving cortisone and those not receiving it, although it was shown that the cortisone had the effect of diminishing the relative concentration of ascorbic acid in the adrenal glands of animals in the groups on the lower intakes of the vitamin.

3. It is concluded therefore that, contrary to some earlier suggestions in the literature, cortisone did not in our experiments influence the overall requirements for vitamin $\mathrm{C}$.

Our thanks are due to Dr A. N. Howard and Mr A. Ward for serving on the panel of assessors. 


\title{
REFERENCES
}

Bland, M. N., Constable, B. J., Harris, L. J. \& Hughes, R. E. (1952a). Biochem. F. 5I, xxxv.

Bland, M. N., Constable, B. J., Harris, L. J. \& Hughes, R. E. (r952b). Congr. int. Biochim. 2. Paris, p. 325 .

Clayton, B. E. \& Prunty, F. T. G. (195 I). Brit. med. J. ii, 927.

Constable, B. J., Harris, L. J. \& Hughes, R. E. (1955). Proc. Nutr. Soc. 14, x.

Eisenstein, A. B. \& Shank, R. E. (1951). Proc. Soc. exp. Biol., N. Y., 78, 619.

Fish, E. W. \& Harris, L. J. (1934). Phil. Trans. B, 223, 489.

Harris, L. J., Bland, M. N., Hughes, R. E. \& Constable, B. J. (1953). Lancet, 264, ro2 I.

Harris, L. J., Mills, I. \& Innes, J. R. M. (1932). Lancet, 223, 235.

Harris, L. J. \& Olliver, M. (1942). Biochem. F. 36, 155.

Harris, L. J. \& Ray, S. N. (1932). Biochem. F. 26, 2067.

Harris, L. J. \& Ray, S. N. (I933a). Biochem. F. 27, 303 .

Harris, L. J. \& Ray, S. N. (1933b). Biochem. F. 27, 2006.

Höjer, J. A. \& Westin, G. (1925). Dent. Cosmos, 67, r.

Hughes, R. E., Harris, L. J., Constable, B. J. \& Bland, M. N. (1952). Biochem. 7. 5I, xxxv.

Hyman, G. A., Ragan, C. \& Turner, J. C. (1950). Proc. Soc. exp. Biol., N.Y., 75, 470.

Key, K. M. \& Elphick, G. K. (I93 I). Biochem. Y. 25, 888.

Mindlin, R. L. \& Butler, A. M. (1937). J. biol. Chem. 122, 673.

Sayers, G., Sayers, M. A., Lewis, H. L. \& Long, C. N. H. (1 944). Proc. Soc. exp. Biol., N. Y., 55, 238.

Szent-Györgyi, A. (1928). Biochem. F. 22, 1387 .

\section{Physiological Undernutrition in the Newborn Guinea-pig}

\author{
By ELSIE M. WIDDOWSON AND R. A. MCCANCE \\ Medical Research Council Department of Experimental Medicine, \\ University of Cambridge \\ (Received 26 March 1955)
}

Physiological undernutrition is a phase in the natural development of some animals. The Atlantic seal is probably the most dramatic example of it among the mammals, for, after a short period of suckling and the deposition of fat in large quantities, the young of this species spend the next few weeks of their lives starving on the beach (Darling, I 947; Amoroso, Goffin, Halley, Matthews \& Mathews, 195I). Only after this period of starvation do they take to the sea in search of their own food. Some of the sea birds go through a similar series of nutritional ups and downs, which have been even less studied than those of the seal. Puppies and kittens may get fat during suckling, only to lose much of the fat when they are weaned, and the human infant has a short period of physiological undernutrition from the moment of birth till the flow of milk is established.

In the course of some work on the chemistry of growth, observations made on the newborn guinea-pig suggested that the animal must pass through a period of physiological undernutrition in the ist week of its life. Since the observations appeared not to have been previously described, it was decided to use this convenient laboratory animal for a study of the effects of a naturally induced undernutrition on the composition of the body. The cause of the undernutrition would seem to be that the 